African Research Review An International Multidisciplinary Journal, Ethiopia

Vol. 10(1), Serial No.40, January, 2016:225-233

ISSN 1994-9057 (Print)

ISSN 2070--0083 (Online)

Doi: http://dx.doi.org/10.4314/afrrev.v10i1.17

\title{
Examination of Ife Bronze Casting Culture and Its Decline in Maintenance Practice in Contemporary Society
}

\author{
Awogbade, Mabel Oluremi, Ph.D. \\ School of Visual and Performing Arts (Fine and Applied Arts Unit) \\ College of Humanities, Management and Social Sciences. \\ Kwara State University, Malete, Ilorin. \\ Kwara State, Nigeria. \\ E-mail: remiamaoawogbade@ yahoo.com \\ Tel: +2347069671790
}

\begin{abstract}
Ile-Ife, the Yoruba ancient city is known for its vibrant cultural environment. This city of ancient civilization and one of the home for bronze casting in the Western region of Nigeria have made significant contributions to the world of culture through its great artistic traditions in terracotta, bead making, bronze and brass casting that predates PreColonial era. This culture of occupational practice has experienced decline as a result of its discontinuity in modern day Ile-Ife. This study therefore investigates the causes of its decline in practice and also examines the maintenance and sustainability of bronze casting in Ile-Ife. In so doing, this study adopts the interview method to enable the researcher investigates the factors responsible for the decline in bronze casting from the families that were once associated with this art. The findings of this study reveals that, the decline is as a result of many factors including the influence of war, western civilization and culture, education, science and technology. Sequel to this influences, those craftsmen who practiced bronze casting also passed on without replacement. This study concludes that in order to resuscitate bronze casting in Ile-Ife, there is the need
\end{abstract}


to set up bronze casting industry to promote the commercial culture in the history of Ife. Furthermore, the spell on the trade should be revoked and the practice of bronze casting should be sustained.

\section{Introduction}

Art is unique and it is a vital part of human experience; throughout history, people record their struggles, their dreams and their lives in works of art. No phenomenon denied of utility survives in a society. According to Olurode (2005), if human development is to be sustained, the cultural heritage should be upheld. Bronze casting should be one of the cultural heritages of Ife. Ife possesses artifacts of great importance and rich culture. The ancient city is known for its artistic, cultural and traditional religion. The rulers of Ife promoted art production such as brass and bronze casting, terracotta, bead-making, carving, weaving and pot making among others. The maintenance and sustenance of Ife art culture is of paramount concern.

Tomas (2009) qualifies Ife art as the highest civilization of Europe and Asia. Probably the time known in Europe as the medieval period was the golden age of West Africa. Ife art is known for the very important role it plays in African art. Leo Frobenius confirm the existence of high civilization in Ife. Although many scholar doubted the origin of Ife Art because of its classical standard. The excellent and classical skill displayed in the execution o f terracotta and bronze heads according to Fagg (1967) compared favorably well with the Greek style. Ife art culture particularly bronze casting is known and respected for naturalistic and stylistic representation.

Ife bronze casting is of great significance, and the production tradition and its values need to be maintained and sustained. Ife art culture, particularly in terra-cotta and bronze works are known and famous for their creative productions but there are little or no written documents on the artists that produced the works and at present, the art is at a declining state. However, the art culture needs to be examined and revived in order to maintain and sustain the culture. This informed the purpose of this study.

An economic growth theory according to Oddleifson (1996), suggests that growth can continue indefinitely, even without technological progress, if human capital (i.e., knowledge and skills embodied in the workforce) is included as a factor of production. Vygotsky (1978) postulates activity theory of social cognition, for a conception of social knowledge that conceives of learning as a transaction between the person and the social environment. According to him, the situation is embedded in community of practice that has history, norms, tools and traditions of practice. To this end Ife art, amongst others need to be maintained and sustained in order to promote economic growth and the rich cultural heritage of Nigeria, and this would educate the global audience and strengthen Nigerian's contribution to the world of art. Hence, IleIfe should be made a place for trade and technological development. 
However, the trust of this paper is to examine the maintenance practice of bronze casting culture in Ile-Ife. The glory of Ife art is insufficient without the maintenance culture of the art. Art is a central part of human experience, knowing that no phenomenon devoid of utility survive in a society. This paper is to investigate the dwindling practice in spite of the great name and contribution Ife Art has brought on history.

\section{Origin of Ile-Ife}

Ile-Ife is known worldwide as the cradle Yoruba ethnic group. It is located in Osun State, South west of Nigeria. Ile Ife houses both Obafemi Awolowo University and the National Historical Museum of Nigeria. It is composed of surrounding towns like Ipetumodu, Edunabon, Yakoyo, Moro, Akinlalu, Ife Tedo. It has a population of 501,952 and lies between latitude $7^{\circ} 28^{\prime} \mathrm{N}$ and $7^{\circ} 45^{\prime} \mathrm{N}$, longitudes $4^{\circ} 30^{\prime} \mathrm{E}$ and $4^{\circ} 34^{\prime} \mathrm{E}$ (Ajala \& Olayiwola 2013). Ile-Ife covers an area of $1846 \mathrm{~km}$ and its western boundary joins the course of Shasha while it's south-eastern boundary River Ooni. However, no such natural features mark the boundary to the north-east or the south (Jeje 1992). The ancient city according to oral tradition is as old as human history. There are four distinct theories ascribed to the origin of Ife. Thus: 1. That, Oduduwa, the son of Olodumare descended with a chain with two hundred deities and landed on an ark at Orafe; 2. That, Oduduwa and his party migrated from the Middle East; 3 . That, Oduduwa and his party descended from the East of present day Ile-Ife; and 4. That, Ile-Ife had being with thirteen separate settlement before the coming of Oduduwa.

From the account of the different versions of the story, one clear point from all is that, Oduduwa featured prominently as the founding father of the political dynasty and the history of origin is centered and woven around his personality (Ogundele 2013).

Ile-Ife is a commercial and trading center, a flourishing cosmopolitan city state that established significant political and religious authority. According to Horton (1979), Ife was the imperial capital of the Yoruba kingdoms between the $10^{\text {th }}$ and the end of the $16^{\text {th }}$ centuries but lost the political aspect of its imperial status with the rise of Benin and the rise of Oyo kingdoms. However, Ife still retains its honour because of the religious sanctity attached to it.

Most families in Ile-Ife are based in patriarchal systems of control. Most people are employed through farming; trading and artisanship: these form their main occupations. However, different families in Ile-Ife specialized in different art industries and the art culture passes from father to son.

\section{Ife Art History}

Ife art is not for art sake. Its artifacts cannot be discussed in isolation without its religion; religion and art of Ife are inseparable. Ife artifacts serve as abode for the spirits being worshipped. They serve as objects of worship representing the images of 
deities. They are used for ritual purposes as well as historical objects for personal memory.

The antecedents of Ife art remain a probability. This is because of the religious flavour surrounding the historical sources. This is perhaps not far from the fact that, to have access into the in-depth information, you must take part in the ceremonies and to take part in the ceremonies, you must be an initiated member. According to Olaniyan and Akinjogbin (1992) "...if a scholar offers to be initiated so that he may have access to the ceremonies and his initiated, he becomes inhibited by secrecy injunctions and the number of taboos which he may have sworn to keep under oath and thus prevented him from divulging or meaningfully citing the useful information in his possession".

Ceremonies marked in Ile-Ife include Obatala, Edi and Olojo among others. According to Ife oral tradition, Obatala was the patron of sculptures, Olodumare gave him the prerogative to create man or woman of shapely or deformed features. Edi was established in remembrance of heroic deeds of Moremi who helped Ife overcome the raids of Igbo. Olojo was established to celebrate Oduduwa who founded and progeny the largest homogenous race south of Sahara. All these ceremonies have socio-cultural and religious relevance and are still marked every year in remembrance of the ancestors.

In 1910, a German archeologist by name Leo Frobenius visited and excavated several site in Ife ancient city, and these brought Ife art into global discourse. Ife art combines terracotta, wood carving, stone carving, beads, dyeing and metal work but Bronze casting made it more famous. Adisa (2013) confirms that "...the visit of Leo Frobenius to Ile-Ife in 1910 ... has gained international recognition. The fame of Ile-Ife was based on its fascinating figures in copper alloy, terra-cotta, stone, and potsherd pavement which surpass all other towns and cities in Yoruba land and indeed Nigeria".

However, lack of information and records on artifacts, prompted many scholar, archeologists and artists rely on scientific method of dating to estimate the beginning of Ife art. Adam (1963) postulates that, Ife Art flourish between $8^{\text {th }}$ and $16^{\text {th }}$ century.

Ife art, according to Eluyemi (1978) might date as far back as earlier days of Ile Ife. He states that "If as Egharevba claims, Oba Ogunola who sent for Igue-igha from Ife to teach art of brass smithing to the Edo people, reigned around A.D 1280, the beginning of brass casting industry in Ife would date prior to 1280".

\section{Ife Bronze Casting}

By Ife oral tradition and information gathered in an interview with Ben Oluyemi; the only renowned surviving bronze caster in Ile-Ife, Ooni Obalufon Ogbogbodini introduced bronze casting technique to Ife. However, Olapade (1992) suggests that metal working technique of Cire-perdu or lost wax must have come from Meroe Sudan. Though there is no evidence to sustain this suggestion. His suggestion 
according to him was based on Shinnie suggestions that Merotic Kingdom in the Nile Valley had a much earlier metallurgic activity than the Ife casting.

Ben Oluyemi explains that Ife metal work can be classified into two branches: Alagbede dudu (Black smith) and Asude (Brass smith). Black smith has to do with forging and beating of metalwork. While Brass smith involves working with nonferrous metals such as lead, copper, silver and alloys. Bronze is an alloy of tin and copper while brass is the alloy of zinc and copper in brass and bronze. This paper is concerned about Ife bronze casting.

The technical process of bronze casting involves rigorous process referred to as Cire Perdue. Cire Perdue is a French term for 'lost wax method' a technique whereby, a model is made in wax over a core of clay. Another layer of clay is built over the wax leaving an opening on top, iron pegs are driven through from outside to the inside core model to prevent shaking. Iron wire is then used to bind the whole mould together. The mould is left to dry and fired to melt the wax layer which pours out from the top opening. Bronze (alloy of tin and copper) melted in a crucible is carefully poured through the same open hole on top to fill the space created by the wax in between the core model and the external clay layer. After solidification of the work, the pegs, external clay layer and the core mould are removed and a hollow bronze figure is produced.

Bronze figures produced were sacred and mostly used by the Ife royalty. The figures were mostly heads (crown of body and the seat of the soul) which depict kings and queens, court attendants, sacrificial victims and other religious deities. Such is the 'Ori Olokun' excavated in 1910 by Leo Frobenius at Igbo Olokun (Groove of Olokun). 'Ori Olokun' bronze is the effigy of Olokun Seniade, the favourite wife of Oduduwa. The effigy has elegant face with perfect lines, highly naturalistic and shows the effect of tranquility of power

\section{The Decline}

As at 1978, Eluyemi pointed out four distinct families that specialized in terracotta and bronze casting in Ile-Ife. They are:

1. Meroko keranjakun of Obalaaye Awonbiogbon compound, Okerewe quarter, Ile Ife. He was said to have learnt the trade from his father.

2. Gbetu of Okiti compound: Gbetu learnt the trade from Meroko keranjakun of Obalaaye Awonbiogbon compound, Ife.

3. Jako family of Ejio Arode compound, Moore quarter, Ife: This family was said to be known for brass casting in the past but presently, no trace of continuation in that clan. 
4. Ben Oluyemi of Obalaaye Compound, Okerewe quarter, Ile Ife: He learnt the trade of smith metal and lost wax process from Gbetu.

Attempt was made to interview the enlisted families of bronze casters in Ife but unfortunately, only Ben Oluyemi is alive. Efforts made to gather information from the family of Meroko Keranjakun of Obalaaye Awonbiogbon compound, Okerewe quarter, Ajibona revealed that Meroko Keranjakun, gave birth to Ajibona who also leant the trade from him. Ajibona had no male child to continue the trade of his father, as metal crafts trade was a business of a male child in Ife.

Visit to Okiti compound revealed that Gbetu learnt the trade from Meroko Keranjakun of Obalaaye Awonbiogbon compound, Ife, and handed the trade down to his son Lamidi Oke. Ejio Arode compound, Moore quarter, Ife was also visited to gather information on Jako bronze/brass casters' family but there was no trace of the trade in the clan: This readily confirmed the findings of Eluyemi. Last and not the list is the family of Ben Oluyemi of Obalaaye Compound, Okerewe quarter, Ile Ife. He learnt the trade of smith metal and lost wax process from Gbetu and studied sculpture abroad.

An interview with Ben Oluyemi, the only re-known bronze caster in Ile-Ife, a sculptor, who carves in wood and stone and cast in brass and bronze. He narrated and blamed the cause of the decline in Ife terra cotta, bronze and brass casting to the elimination of the craftsmen and the spell placed on the traditional industry by Ooni Ekun. That at a time, Lajuwa a palace courtier contracted a craftsman to produce a face mask of Obalufon in bronze and he used it to usurp the throne; appearing to people as Ooni when indeed, the Ooni was late (died). When the trick was uncovered, a new Ooni was installed... and he invited all the craftsmen: bronze casters, wood and stone carvers, young and old to a banquet in his palace with promises of abundant gifts.

The invitation was open for days and as each day passed by, the number of craftsmen increased. As there were no more guests coming in, it was assumed that all craftsmen, old and young were present and the Ooni ordered the elimination of all. Afterwards, Ooni Ekun placed a spell that, no one again should practice the act of bronze and brass casting. The only few craftsmen, who did not attend the bouquet were left and because of fear of spell abandoned the trade. According to the oral tradition, almost all the indigene loss interest ever since and one hardly sees an Ife indigene interested in the trade.

It was gathered from literature that other factors might have contributed to the decline too. Ogundele (2013) opines that internecine war between Ife and Modakeke in the mid-19th century, which led the colonial government to proscribe all iron smelting sites in Ife, might have contributed greatly to the decline. Olapade (2013) ascribes the decline to the takeover of national administration by the British colonial masters and the introduction and acceptance of Christianity and Islamic religion which 
despise the use of art forms as representations of gods. Other findings include the introduction of western education in the late $19^{\text {th }}$ century and the advent of science and technology.

Perceived decline in bronze casting had attracted expected reactions; some opposed the idea of decline while others argue strongly in support of the decline. The decline to some was as a result of the doctrine of foreign religions, some attribute it to the development of science and technological advancement, while to others; it is the after effect of war. To the majority, it was the effect of a spell placed on the trade by the Ooni.

\section{Conclusion and Recommendations}

One is not only amazed by the quality and quantity of bronze works produced in Ile-Ife but would also conclude that Ife processes a very rich culture of art and tradition. Unfortunately the art traditions are declining as a result of many factors including the influence of war, western civilization, and culture, education, foreign languages, science and technology. Sequel to this influence, those craftsmen who practiced bronze casting also passed on without replacement. Presently, it is noted that only Ben Oluyemi is left in the business of bronzes casting in Ile-Ife. May youths do not see the sensibility of practicing the art.

On the strength of everything said so far, the following recommendations were made:

- It is important to stress here that the greatness and the leadership chances of a nation lies in their culture and their art. Hence, bronze casting tradition, synonymous with Ile-Ife and known around world needs to be revived, sustained and maintained.

- The public attitude need be improved towards the appreciation of indigenous culture. There is the need to set up bronze casting industry to promote the commercial culture in the history of Ife

- The spell on the trade should be revoked and the practice of bronze casting should be sustained.

- The national museum situated in Ile-Ife needs to encourage and assist trainees interested in bronze casting to acquire skills with the latest technology.

- It is also important to organize and form a guild on the job to develop and sustain the art tradition.

- More research need to be carried out and documented on the art culture of the people of Ile-Ife. 
- To help revive traditional arts and crafts, government should include the study of indigenous art traditions in the 9 year basic education curriculum as core subject as it is in Ghana and other countries.

\section{References}

Adam, L. (1963). Primitive Art. 3rd Edition. London: Cassel.

Adisa, O. (2013). Archaeology of Ife: Exposing Yoruba Civilization. Publication National Museum, Ile-Ife. 1(1), 5 and 16.

Ajala, O. A. \& Olayiwola, A. M. (2013). Assessment of the growth of Ile-Ife, Osun State Nigeria, using multi-temporal images. Journal of Geography and Geology, 5(2), 43-53 Canadian Centreof Science and Education. Retrieved from http://www.ccsence.org

Akinjogbin, I. A. \& Olaniyan, R. A. (1992). Sources of Ife history. In Akinjogbin, I.A (ed.). The cradle of a race Ife beginning to1980. Port-Harcourt, Nigeria: Sunray Publications Ltd.

Eluyemi, O. (1978). The Living Art and Craft of Ile-Ife. Ile-Ife: Adesanmi Printing Works

Fagg, W. (1967). Ife in the History of West African Sculpture. In Mortimer Wheeler (ed.). New Aspects of Archaeology Series. New York \& London: McGrew-HILL Book.

Horton, R. (1979). The Economy of Ife from C.A.D. 900-C.A.D 1700. In Akinjogbin, I.A (ed.).The Cradle of a Race Ife Beginning to1980. Port-Harcourt, Nigeria: Sunray Publications Ltd.

Jeje, L.K. (1992). Ife Division - The Physical Elements of Environment. In Akinjogbin, I.A (ed.). The Cradle of a Race Ife Beginning to1980. Port-Harcourt, Nigeria: Sunray Publications Ltd.

Oddleifson, E. (1996). Finding the creative power within us to control our bodies and shape our destinies. Retrieved January 23, 2016 from http//www.newhorizons.org.

Ogundele, J.O. (2013a). Ife: A centre of world civilization. Publication of Ife National Museum 1(1), pp. 4-6

Ogundele, J. O. (2013b). Ife Archeology and Material Culture in Retrospect. Publication of Ife National Museum (1)1, p.5.

Olapade, O. (1992). Ife Classical Art. In Akinjogbin, I.A (ed.).The Cradle of a Race Ife Beginning to1980. Port-Harcourt, Nigeria: Sunray Publications Ltd. 
AFRREV, 10 (1), S/NO 40, JANUARY, 2016

Olurode, L \& Olusanya, P. O. (2005). Nigerian Heritage: A Yoruba Example. Lagos: Rebonik Publications Limited.

Tomas, S. (2009). Head of an Ife King. YouTube Retrieved from http://wwwyoutube.com

Vygotsky, L. S. (1978). Mind in Society: In Michael C., Vera J., Sylvia S. \& Ellen S. (ed.). The Development of Higher Psychological Processes. Cambridge, Massachusetts London, England: Harvard University Press. 